\title{
PENGEMBANGAN ENSIKLOPEDIA KELOMPOK TENAGA KERJA HUKUM DALAM LAYANAN BIMBINGAN KLASIKAL DI SMA NEGERI 5 BOGOR
}

\author{
Djunaedi $^{1}$ \\ Rika Amalia Permatasari ${ }^{2}$
}

\begin{abstract}
Abstrak
Peserta didik SMA sedang berada pada tahap perkembangan eksplorasi karir membutuhan berbagai informasi karir. Berbagai alternatif informasi karir ini kemudian direncanakan untuk menjadi sebuah keputusan karir yang sesuai dengan minat, bakat dan kemampuan peserta didik. Peserta didik memerlukan sebuah sumber informasi karir untuk menunjang hal tersebut. Penelitian ini bertujuan untuk mengembangkan ensiklopedia kelompok tenaga kerja hukum di Indonesia bagi peserta didik SMA Negeri 5 Bogor agar dapat memperoleh informasi mengenai kelompok tenaga kerja hukum di Indonesia. Ensiklopedia kelompok tenaga kerja hukum akan digunakan dalam layanan bimbingan klasikal bidang karier dengan topik kelompok tenaga kerja hukum. Penelitian ini ditujukan untuk kelas X, XI, dan XII. Populasi penelitian ini adalah peserta didik SMA Negeri 5 yang terdaftar dalam data sekolah. Sampel penelitian ini adalah sampel terjangkau yaitu kelas X dan XI menggunakan teknik sampling Accidentally Random Sampling. Metode penelitian yang digunakan adalah metode kuantitatif model penelitian dan pengembangan dengan desain penelitian ADDIE (Analysis, Development, Design, Implementation, Evaluation). Adapun tahap penelitian dibatasi meliputi Analisis, Desain dan Pengembangan. Instrumen yang digunakan adalah angket dan wawancara. Penilaian media dilakukan oleh ahli media dan ahli materi. Berdasarkan hasil validasi ahli menyatakan media sangat layak sebesar $97 \%$ penilaian dari ahli media, $87 \%$ peniaian dari ahli materi, $86.4 \%$ penilaian dari peserta didik dan ketercapaian tujuan sebesar $84 \%$.

Kata Kunci: Ensiklopedia, Tenaga Kerja, Hukum, Bimbingan Klasikal, Desain ADDIE
\end{abstract}

\begin{abstract}
This study aims to develop encyclopedia of legal labor work in Indonesia for 5 Bogor Senior High School students to get information about the group of legal workers in Indonesia. Encyclopedia of legal labor will be used in classical guidance on career field with the topics of legal labor. This study is intended for $10^{\text {th }}, 11^{\text {th }}$, and $12^{\text {th }}$ grades. The population of this study were students of 5 Bogor Senior high School who were registered in the school data. The samples were taken from $10^{\text {th }}$ and $11^{\text {th }}$ grades students using Accidentally Random Sampling sampling technique. The method used is quantitative method Research and Development model, design of ADDIE. The stage of research limited to Analysis, Design, and Development. The instrument used are questionnaire and direct interview. The media assessment is conducted by validators consist of media expert, and content expert. Based on expert validation conducted by media expert is $97 \%$, the media expert judgement is $87 \%$,
\end{abstract}

\footnotetext{
${ }^{1}$ Universitas Negeri Jakarta, djunaedi_unj@yahoo.com

${ }^{2}$ Universitas Negeri Jakarta, rikaprmtsr@gmail.com
} 
content expert judgement is $86,4 \%$, and students judgement and goal attainment are $84 \%$.

Keyword : Encyclopedia, Labor, Legal, Classical Guidance, Design of ADDIE

Peserta didik SMA yang pada umumnya berusia 15-18 tahun berada pada fase menghadapi berbagai pilihan untuk menentukan masa depan karier mereka. Memasuki tahap awal SMA mereka akan mengalami kebingungan dalam memilih jurusan IPA atau IPS. Setelah itu ketika mereka menginjak tahun terakhir di SMA mereka akan dihadapkan pada pilihanpilihan studi lanjutan yang sesuai dengan karier yang mereka inginkan. Pada fase ini, remaja yang sedang duduk di bangku SMA sedang mengalami masa perkembangan karier dimana mereka akan menentukan berbagai pilihan karier dan kemudian membuat keputusan karier (Sisca \& Gunawan, 2015). Tentunya untuk menunjang pembuatan keputusan karier yang tepat, peserta didik SMA harus mengumpulkan berbagai informasi karier. Hal ini di ditegaskan oleh Santrock (2003) bahwa remaja pada tahap ini sedang melakukan eksplorasi terhadap berbagai jalur karier, dan tahapan ini merupakan tahapan yang penting bagi remaja. Dalam masa eksplorasi ini, merencanakan karir yang tepat dengan mengenali minat dan bakat dirinya akan membuat peserta didik mencapai kematangan kariernya.

Pekerjaan merupakan sesuatu yang sangat penting dalam masyarakat kita. Dengan adanya pekerjaan masyarakat dapat melakukan kegiatan-kegiatan pengembangan ilmu dan penerapan ilmu (Sidharta, 2015). Karena melalui pekerjaan, ilmu yang telah dipelajari dapat diterapkan sesuai dengan kebutuhan yang harus dilakukan. Dalam pekerjaan aspek paling penting adalah tenaga kerja. Secara sederhana tenaga kerja adalah orang yang melakukan pekerjaan. Namun definisi mengenai tenaga kerja dapat dijelaskan lebih dalam menurut Undang-Undang Ketenagakerjaan Nomor 13 tahun 2003 yaitu setiap orang yang mampu melakukan pekerjaan guna menghasilkan barang dan/atau jasa untuk memenuhi kebutuhan sendiri maupun untuk masyarakat.

Masyarakat modern akan berusaha untuk memperoleh perlindungan hukum agar dapat menjalani kehidupannya secara aman. Di Indonesia, berdasarkan data dari Badan Pusat Statistik (BPS) pada tahun 2016 menunjukkan bahwa angka kriminalitas naik sebesar 1,2 persen dari sebelumnya mencapai 357.197 kasus. Tingginya angka kriminalitas menimbulkan keresahan masyarakat modern akan hidup yang tidak aman. Oleh karena banyaknya permasalahan yang berkaitan dengan kehidupan manusia ini, maka masyarakat modern akan berusaha mencari bantuan kepada tenaga kerja hukum di Indonesia. Untuk menegakkan keadilan dan perlindungan hukum ini, tenaga kerja hukum dibutuhkan untuk membantu dengan penuh kesadaran dan tanggung jawab untuk mempertemukan hukum dengan tuntutan masyarakat modern yang urgent (Sumaryono, 1995). Hal ini yang membuat tenaga kerja hukum di Indonesia akan sangat dibutuhkan dalam sistem masyarakat modern. Mengingat besarnya kebutuhan tenaga kerja hukum di Indonesia maka kelompok pekerjaan hukum menjadi sektor yang memiliki peluang besar bagi peserta didik sebagai calon tenaga kerja.

Tenaga kerja hukum adalah seseorang yang bekerja dalam upaya penegakkan hukum dan menjaga ketertiban hukum. Menurut Sidharta (2015) tenaga kerja hukum berkaitan dengan masalah mewujudkan dan memelihara ketertiban yang berkeadilan dalam kehidupan masyarakat. Tenaga kerja hukum juga bekerja dalam mengatur berbagai kaidah perilaku masyarakat agar sesuai dengan norma hukum yang berlaku.

Penting bagi peserta didik sebagai calon tenaga kerja mengetahui informasi penting mengenai tenaga kerja hukum. Berdasarkan hasil studi pendahuluan kepada peserta didik SMA Negeri 5 Bogor menyatakan bahwa 
sebanyak $65.7 \%$ peserta didik membutuhkan informasi mengenai tenaga kerja hukum. Peserta didik merasa butuh informasi mengenai berbagai tenaga kerja hukum yang ada di Indonesia mengingat mereka sedang pada masa eksplorasi karir untuk dapat mempertimbangan keputusan karir yang tepat. Sedangkan pada pelaksanaannya, peserta didik belum memperoleh informasi mengenai kelompok tenaga kerja hukum. $77,1 \%$ peserta didik menyatakan bahwa mereka belum mendapatkan informasi mengenai kelompok tenaga kerja hukum dari guru BK.

Bimbingan konseling dapat dikatakan sebagai sebuah fasilitas pendidikan yang menekankan pada optimalisasi potensipotensi dalam diri peserta didik agar tercapainya aktualisasi secara positif (Farozin, et al., 2016). Kegiatan bimbingan klasikal adalah layanan yang diberikan kepada peserta didik dalam skala kelas yang berorientasi pada pemberian informasi dalam bidang pribadi, sosial, belajar serta karier secara sistematis dan terencana dengan berdasarkan pada kurikulum bimbingan (Mukhtar, Budiamin, \& Yusuf, 2016). Kegiatan bimbingan klasikal dapat menjadi kegiatan yang secara efektif diberikan kepada peserta didik dalam memberikan informasi sebagai upaya preventif dan upaya pengembangan diri bagi peserta didik. Media belajar dapat menjadi sarana penunjang agar pemberian informasi dapat terjadi dengan cara yang efektif dan inovatif.

Sebanyak $51.4 \%$ peserta didik di SMA Negeri 5 Bogor menyatakan bahwa media buku ensiklopedia kelompok tenaga kerja hukum akan menarik bagi mereka untuk mencari informasi terkait tenaga kerja hukum. Hal ini karena mereka menyatakan bahwa mereka akan mendapatkan informasi yang banyak mengenai kelompok pekerjaan hukum. Hasil penelitian dan data yang diperoleh menunjukkan keberadaan media ensiklopedia dapat diterima dan dirasa menarik bagi peserta didik untuk mendapatkan informasi mengenai pekerjaan, maka penulis berencana untuk membuat ensiklopedia tenaga kerja hukum sebagai media informasi yang dapat menjawab kebutuhan peserta didik.

\section{Buku Ensiklopedia}

Buku ensiklopedia atau yang biasa disebut ensiklopedia merupakan media cetak pembelajaran yang didalamnya terdapat informasi dasar dan penjelasan secara komprehensif mengenai suatu cabang ilmu pengetahuan (Prihartanta, 2015). Ilmu pengetahuan tersebut di jabarkan menjadi topik-topik bahasan secara terperinci agar lebih mudah dimengerti dan dipahami. Dalam ensiklopedia topik-topik bahasan disusun berdasarkan abjad, kategori, dan volume penerbitan yang dirangkai secara utuh (Alfajria \& Sudjuni, 2015). Jika membahas mengenai ensiklopedia tenaga kerja hukum maka system pengurutannya adalah diurutkan tenaga kerja hukum berdasarkan abjad A hingga Z. Sistem penyusunan ini memudahkan penjelajahan informasi dalam ensiklopedia.

Ensiklopedia memuat konten berupa informasi-informasi suatu istilah pengetahuan yang tidak hanya dijelaskan dalam bentuk definisi melainkan pula contoh-contoh dalam istilah tersebut (Nurhatmi, Rusdi, \& Kamid, 2015). Sehingga didalam ensiklopedia kumpulan informasi pengetahuan menjadi lebih kaya. Tidak hanya berupa tulisan, ensiklopedia memuat berbagai gambar agar ensiklopedia terkesan menarik.Kelengkapan materi dan adanya beberapa contoh gambar yang dapat diamati langsung oleh peserta didik (Iskandar, Budijanto, \& Amirudin, 2016). Hal yang membedakan antara ensiklopedia dengan buku teks pada umumnya terletak pada adanya komposisi gambar atau ilustrasi yang seimbang dengan teks sehingga peserta didik dapat lebih memahami materi secara konstektual.

Penyusunan ensiklopedia perlu memperhatikan beberapa hal penting sehingga ensiklopedia menjadi sebuah media pembelajaran yang menarik dan bermanfaat.Pernyataan dari Badan Standar Nasional Pendidikan (BSNP) menjadi dasar 
dalam penyusunan ensiklopedia ini. BSNP menyatakan bahwa media pembelajaran seharusnya memenuhi tiga komponen: (1) memenuhi komponen isi yang terdiri atas cakupan materi, akurasi materi, kemutakhiran, mengandung wawasan produktivitas, memunculkan keingintahuan, mengembangkan kecakapan hidup, mengembangkan wawasan kebhinekaan, dan mengandung kawasan kontekstual, (2) komponen kebahasaan harus sesuai dengan perkembangan perserta didik, komunikatif, dialogis/interaktif, lugas, alur berpikir runtut, koherensi, sesuai kaidah bahasa Indonesia yang baku, dan penggunaan symbol dan istilah yang benar, dan (3) komponen penyajian teridiri dari teknik penyajian, pendukung penyajian materi, dan penyajian pembelajaran (Iskandar, Budijanto, \& Amirudin, 2016).

\section{Tenaga Kerja Hukum}

Tenaga kerja hukum merupakan seseorang yang sudah masuk kedalam dunia pekerjaan yang melayani orang lain dalam bidang hukum. Tenaga kerja hukum pula berkaitan dengan menjaga ketertiban yang berkeadilan dalam kehidupan bermasyarakat (Sidharta, 2015). Tenaga hukum pula melakukan penelitian mengenai permasalahan hukum menyarankan klien mengenai aspek hukum dari suatu masalah, membela kasus atau melakukan penuntutan di pengadilan hukum, memimpin proses peradilan di pengadilan, dan merancang undang-undang dan peraturan. Adapun tugas pokok tenaga kerja hukum adalah memberikan saran kepada klien mengenai hukum, melakukan bisnis legal atas nama klien, dan melakukan litigasi bila diperlukan, atau memimpin proses peradilan dan menjatuhkan putusan di pengadilan. Pengawasan pekerja lain dapat disertakan (Amir, et al., 2014). Sehingga tenaga kerja hukum bekerja dalam sektor hukum yang berusaha dalam pelayanan menjaga ketertiban umum serta menegakkan keadilan hukum di masyarakat.

Dalam kelompok tenaga kerja hukum terdapat beberapa tenaga kerja yang lebih rinci. Pengacara merupakan salah satu tenaga kerja paling popular dikalangan masyarakat. Pengacara bekerja kepada klien untuk memberikan saran tentang hukum pada berbagai bidang, selain itu pengacara juga menyusun dokumen hukum, mewakili klien sebelum administrasi atau pengadilan dan membela kasus atau melakukan penuntutan di pengadilan, atau menginstruksikan pengacara untuk membela di tingkat pengadilan yang lebih tinggi (Amir, et al., 2014). Pengacara sebagai pembela juga akan bertugas untuk mewakili klien dalam segala proses peradilan baik pidana maupun perdata (Farr \& Shatkin, 2007).

Jaksa adalah pejabat fungsional yang diberi wewenang bertindak sebagai penuntut umum, pelaksana putusan Pengadilan, atau kewenangan lainnya yang diamanatkan undang-undang. Jaksa merupakan orang yang melakukan penyidikan dan sebagai pelaksana putusan pengadilan yang berkekuatan hukum tetap dalam perkara pidana (Amir, et.al., 2014).

Hakim adalah pejabat yang ditunjuk dalam hal memeriksa, mengadili perkaraperkara baik perkara perdata, pidana maupun berbagai permohonan (Sidharta, 2015). Seorang hakim harus memiliki keterampilan mendengar aktif, membaca secara komprehensif, berfikir kritis, menilai dan membuat keputusan serta menulis deduktif (Farr \& Ludden, 2002). Keterampilan-keterampilan ini akan mendukung kinerja hakim dalam proses mengadili perkara.

Polisi Republik Indonesia atau yang biasa disebut dengan POLRI berdinas aktif pada pelayanan masyarakat sipil bertugas dalam melaksanakan peran memelihara keamanan danketertiban masyarakat, menegakkan hukum, serta memberikan perlindungan, pengayoman dan pelayanan kepada masyarakat dalam rangka terpeliharanya keamanan dalam negeri (Amir, et al., 2014).

Menurut KBJI (Amir, et al, 2014), tugas pokok dari seorang notaries adalah memberikan penyuluhan hukum untuk dan 
atas tindakan hukum yang dilakukan notaris atas permintaan kliennya; membuat akta otentik mengenai semua perbuatan, perjanjian, dan ketetapan yang diharuskan oleh peraturan perundangan dan/atau yang dikehendaki oleh yang berkepentingan, untuk dinyatakan dalam akta otentik, menjamin kepastian tanggal pembuatan akta, menyimpan akta, memberikan grosse, salinan dan kutipan akta, semuanya sepanjang pembuatan akta tersebut tidak ditugaskan atau dikecualikan kepada pejabat atau orang lain yang ditetapkan oleh undangundang; mengesahkan tanda tangan dan menetapakan kepastian tanggal pembuatan surat di bawah tangan dengan mendaftar dalam buku khusus (legalisasi).

Arbiter adalah tenaga kerja hukum yang bekerja pada urusan hukum arbitrase. Bertugas untuk memberikan putusan mengenai sengketa tertentu yang diserahkan penyelesaiannya melalui arbitrase. Seorang arbiter berasal dari sektor swasta seperti firma hukum sehingga dapat dikatakan sebagai hakim partikelir (Winarta, 2015). Dalam menentukan arbiter dalam sengketa, kedua belah pihak yang sedang berselisih mempunyai hak untuk memilih arbiter yang akan menjadi wasit dalam persengketaan tersebut (Witasari, 2011). Sehingga tidak akan terjadi keberpihakkan arbiter terhadap salah satu pihak yang bersengketa.

Penyelesaian perselisihan melalui mediasi ini diatur dalam Pasal 8 sampai Pasal 16 UU PPHI. Mediasi dipimpin oleh mediator yang berada di setiap kantor instansi yang bertanggung jawab di bidang ketenagakerjaan kabupaten/kota. Dalam menjalankan tugasnya, mediator harus mengupayakan agar tercapai kesepakatan di antara pihak yang bertikai.

Sesuai dengan Pasal 1 angka 13 UU PPHI, konsiliasi hanya berwenang menangani perselisihan kepentingan, perselisihan PHK dan perselisihan antar serikat pekerja. Artinya, konsiliasi tidak berwenang atas perselisihan hak. Seorang konsiliator baru bisa bertindak untuk menangani perkara ketika ada permintaan tertulis dari para pihak.
Juru sita melaksanakan semua perintah yang diberikan oleh ketua sidang; menyampaikan pengumuman, teguranteguran dan pemberitahuan penetapan atau putusan pengadilan menurut cara-cara berdasarkan ketentuan Undang-undang; melakukan penyitaan atas perintahketua pengadilan; membuat berita acara penyitaan, yang salinan resminya diserahkan kepada pihak-pihak yang berkepentingan; melaksanakan berhubungan dengan upaya hukum,melakukan pemanggilan, melakukan tugas pelaksanaan putusan pengadilan yang dipimpinoleh ketua pengadilan dan membuat berita acara pelaksanaan putusan yang salinan resminya disampaikan kepada pihak-pihak yang berkepentingan; melakukan penawaran pembayaran uang, serta membuat berita acara penawaran pembayaran uang dengan menyebutkan jumlah dan uraian mata uang yang ditawarkan (Amir, et al., 2014).

Paralegal membantu pengacara yang berpraktik dan melayani klien dalam memelakukan interview langsung dengan klien; melakukan investigasi di tempat kejadian perkara dan interview saksi-saksi; melakukan investigasi dan membuat fakta statistic dan studi dokumen; melakukan studi hukum; membuat rancangan dokumen hukum, atau pembelaan; membuat ringkasan pemeriksaan dan kesaksian; menghadiri pelaksanaan tindakan hukum; dan membuat dan menandatangani surat menyurat sepanjang ada kejelasan akan status asisten hukum dan surat menyurat tersebut bukan pendapat hukum. Seorang paralegal harus memiliki keterampilan dasar membaca dan menulis, sikap bertanggung jawab serta kemampuan berbicara dan mendengarkan klien dengan baik (Likoff, 2009).

Detektif merupakan pekerjaan yang mengumpulkan, menganalisa, menyusun dan melaporkan informasi mengenai individu atau organisais kepada klien, atau mendeteksi terjadinya tindakan melanggar hukum atau pelanggaran aturan dalam organisasi swasta (Amir, et al., 2014).

Setiap perusahaan pasti memiliki urusan-urusan yang berkaitan dengan 
hukum seperti masalah perjanjian dan kontrak kerja juga berkas-berkas yang berkaitan dengan hukum perusahaan. Maka dari itu setidaknya dibutuhkan tenaga kerja hukum yang mengatur hal tersebut, biasa disebut staf legal atau legal officer. Tugas pokok seorang legal officer adalah Review perjanjian kerjasama dengan pihak kedua, Pengarsipan dokumen hukum Internal, Bertanggung jawab atas tata laksana dokumen hukum.

\section{METODE PENELITIAN}

Penelitian dilaksanakan di Sekolah Menengah Atas Negeri 5 Bogor. Metode penelitian yang digunakan dalam penelitian ini adalah survey sedangkan jenis penelitiannya adalah penelitian dan pengembangan yang menghasilkan dan mengembangakan produk tertentu dan selanjutnya diuji efektivitas produk tersebut dalam proses belajar (Sugiyono, 2012). Penelitian ini akan menggunakan desain penelitian berdasarkan pendekatan ADDIE dengan tahapan (1) Analisis, (2) Desain, (3) Pengembangan, (4) Evaluasi, dan (5) Implementasi.

Populasi target dalam penelitian ini adalah seluruh peserta didik SMA Negeri 5 Bogor. Populasi terjangkau pada penelitian ini adalah seluruh peserta didik kelas $X$ dan kelas XI yang memenuhi kriteria pengguna. Teknik pengumpulan sampel yang digunakan adalah Accidental Sampling. Teknik ini merupakan teknik pengambilan sampel secara kebetulan sehingga sampel dipilih adalah orang-orang yang dapat dijangkau oleh peneliti sesuai dengan karakteristik yang diinginkan oleh peneliti.

\section{HASIL PENELITIAN}

Pengembangan ensiklopedia kelompok tenaga kerja hukum hanya akan melalui 3 tahapan berdasarkan desain penelitian ADDIE. Hal ini disebabkan atas dasar pertimbangan keterbatasan waktu penelitian. Sehingga tahapan penelitian yang dilakukan hanyalah analisis, desain dan pengembangan. Desain media ensiklopedia kelompok tenaga kerja hukum menggunakan aplikasi Adobe PhotoShop versi 7. Media ensiklopedia kelompok tenaga kerja hukum berisi informasi mengenai syarat-syarat, tahapan, pendidikan yang ditempuh, nilai-nilai, asas, keterampilan, arah minat, tipe kepribadian, kondisi fisik kerja, keuntungan, resiko dan peluang tenaga kerja hukum.

Setelah menyelesaikan proses desain dan pencetakkan, langkah selanjutnya adalah melakukan evaluasi formatif yang dilakukan oleh ahli materi dan ahli media. Validator uji ahli media untuk ensiklopedia kelompok tenaga kerja hukum adalah Mita Septiani, M.Pd yang merupakan dosen Program Studi Teknologi Pendidikan Universitas Ibn Khaldun Bogor yang juga merupakan mahasiswa S3 Teknologi Pendidikan Universitas Negeri Jakarta. Validator uji ahli materi untuk ensiklopedia kelompok tenaga kerja hukum adalah Wening dosen Program Studi Bimbingan Konseling Universitas Negeri Jakarta. Selain itu peneliti melakukan uji pilot kepada kelompok kecil di SMA Negeri 5 Bogor. Jumlah peserta didik yang menjadi subjek dalam uji pilot ini sebanyak 10 orang yang merupakan peserta didik kelas XII IIS B.

Berdasarkan hasil validasi ahli media, ensiklopedia kelompok tenaga kerja hukum dikatakan sangat layak untuk dijadikan media pembelajaran dengan persentase sebesar $97 \%$. Dari aspek keterbacaan teks, keserasian warna, ukuran fisik, bahan dan desain mendapatkan penilaian dengan persentase $100 \%$, lalu pada aspek kualitas gambar mendapatkan penilaian dengan persentase $87.5 \%$ dengan catatan masih ada beberapa gambar yang kurang jelas. Lalu untuk ruang dan penggunaan media masingmasing mendapatkan persentase penilaian 95\% dan 96\% dengan catatan akan lebih baik jika ditambahkan indeks dan glosarium.

Berdasarkan hasil validasi ahli materi, materi yang terdapat dalam ensiklopedia kelompok tenaga kerja hukum memperoleh persentase penilaian sebesar $86 \%$ dengan kategori sangat layak. Dan materi kelompok tenaga kerja hukum mendapatkan persentase 
penilaian sebesar $88 \%$ dengan kategori sangat layak.

Berdasarkan hasil penilaian peserta didik terhadap media didapatkan hasil persentase sebesar $86.6 \%$ sehingga masuk kedalam kategori sangat layak. Ensiklopedia kelompok tenaga kerja hukum mencapai tujuan pembelajaran yang telah direncanakan dengan persentase total sebesar $84 \%$.

Adapun kesimpulan persentase penilaian dapat disimpulkan dalam grafik berikut:

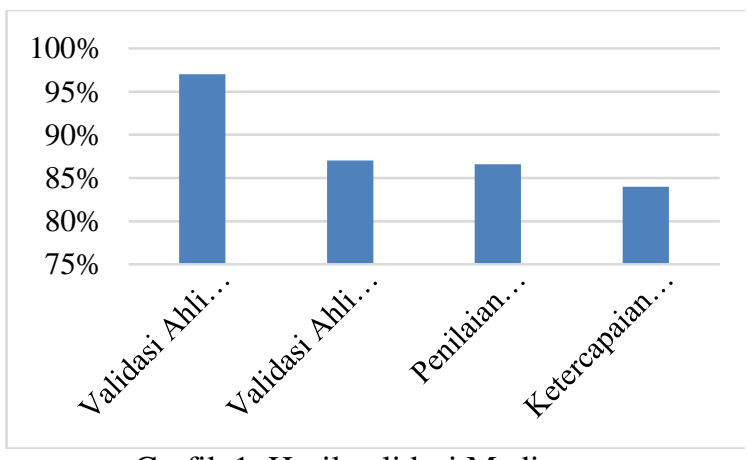

Grafik 1. Hasil validasi Media

Keterbatasan dari segi materi yang disadari oleh peneliti adalah peneliti kurang memberikan penjelasan materi dan kata-kata khusus yang mungkin sulit dimengerti oleh masyarakat awam. Peneliti belum mencari mengenai definisi atau penjelasan dari sub informasi dalam ensiklopedia yang memungkinkan peserta didik mengalami kebingungan dalam mengumpulkan informasi dari sub informasi. Pada sub informasi kondisi fisik kerja, peneliti kurang memberikan gambaran dalam kondisi sebenarnya mengenai kondisi fisik kerja setiap tenaga kerja hukum. Peneliti masih terbatas mencari informasi kondisi sebenarnya mengenai kondisi fisik kerja. Kemudian peneliti juga belum dapat menambahkan beberapa informasi pelengkap yang kurang seperti mengenai tenaga kerja paralegal.

Dari segi media, beberapa hal sudah melalui perubahan media namun masih terdapat keterbatasan seperti gambargambar yang terdapat didalam konten masih kurang menggambarkan isi penjelasan. Serta gambar-gambar tokoh masih kurang representatif. Gambar pada ensiklopedia pun masih bersifat terlalu privat namun peneliti belum mendapatkan izin resmi dari kepemilikan gambar tersebut, sehingga peneliti belum memikirkan dampak dari penggunaan gambar dalam ensiklopedia kelompok tenaga kerja hukum.

\section{KESIMPULAN}

Penelitian ensiklopedia kelompok tenaga kerja hukum dilakukan untuk menjawab kebutuhan peserta didik di SMA Negeri 5 Bogor yang membutuhkan informasi mengenai kelompok tenaga kerja hukum namun belum mendapatkan informasi tersebut dari guru BK. Penelitian ini melewati beberapa tahapan berdasarkan jenis penelitian ADDIE, namun atas dasar pertimbangan waktu maka peneliti hanya akan sampai pada tahap pengembangan media.

Berdasarkan validasi uji ahli media, ensiklopedia kelompok tenaga kerja hukum dinyatakan sangat layak dengan persentase penilaian sebesar 97\%. Sedangkan untuk validasi uji ahli materi juga dinyatakan sangat layak dengan persentase penilaian sebesar $87 \%$. Lalu pada peserta didik dilakukan uji pilot untuk menilai aspek media dan ketercapaian tujuan pembelajaran. Penilaian media dari peserta didik dianggap sangat layak dengan persentase penilaian $86.4 \%$ dan ketercapaian tujuan dianggap sangat layak dengan persentase skor penilaian $84 \%$. Sehingga pengembangan ensiklopedia kelompok tenaga kerja hukum dianggap sangat layak untuk digunakan dalam layanan bimbingan klasikal. Meskipun dalam kategori sangat layak, peneliti menyadari masih ada keterbatasan dalam penelitian ini dari segi media maupun materi.

\section{DAFTAR PUSTAKA}

Alfajria, N., \& Sudjuni, I. (2015). Ensiklopedia tumpeng. Jurnal Tingkat Sarjana Bidang Senirupa Dan Desain, 1, 1-10.

Amir, R., Iriani, D., Ariyanto, T., Haryanto, D., Rokhimah, S., Rejeki, S., ... Listianingrum, 
T. (2014). Klasifikasi baku jabatan Indonesia. Jakarta: Kementerian dan Ketenagakerjaan Badan Pusat Statistik.

Farozin, M., Suherman, U., Triyono, Prawoko, B., Hafina, A., Rustiana, Y. R., ... Sukmaja. (2016). Panduan Operasional Penyelenggaraan Bimbingan dan Konseling Sekolah Menengah Atas (SMA). Jakarta: Kementerian Pendidikan dan Kebudayaan Direktorat Jenderal Guru dan Tenaga Kependidikan.

Farr, M., \& Ludden, L. (2002). O'NET dictionary of occupational titles. Indianapolis: JIST Publishing.

Farr, M., \& Shatkin, L. (2007). ONET: Dictionary of occupational titles (Fourth ed.). Canada: JIST Publisher.

Iskandar, Budijanto, \& Amirudin, A. (2016). Pengembangan buku teks geografi dengan struktur penulisan ensiklopedia. Jurnal Pendidikan: Teori, Penelitian dan Pengembangan, 1(4), 148-154.

Likoff, L., (2009). Career discovery Encyclopedia (7th ed.). New York: Fegusson Infobase Publishing.

Mukhtar, Budiamin, A., \& Yusuf, S. (2016). Program layanan bimbingan klasikal untuk meningkatkan self-control siswa. Psikopedagogia, 5(1), 1-16.

Nurhatmi, J., Rusdi, M., \& Kamid. (2015). Pengembangan ensiklopedia digital teknologi listrik berbasis Contextual Learning and Teaching (CTL). Edu-Sains, 4(1), 37-42.

Prihartanta, W. (2015). Ensiklopedia Umum (Nasional). Jurnal Adabiya, 5(85), 1-14..

Santrock, J. W. (2003). Adolescence: Perkembangan remaja. Jakarta: Erlangga.

Sidharta, B. A. (2015). Etika dan kode etik profesi hukum. Veritas et Justitia, 1(1), 220249.

Sisca \& Gunawan, W. (2015). Gambaran adaptabilitas karier remaja. Jurnal Psikologi, 11(2), 111-119.

Sugiyono. (2012). Cara mudah menyusun skripsi, tesis, dan disertasi. Bandung: Alfabeta

Sumaryono, E. (1995). Etika profesi hukum. Yogyakarta: Penerbit Kanisius.

Winarta, F. H. (2015). Kode etik sebagai suatu pedoman bagi para arbiter. Indonesia Arbitration Quarterly Newsletter, 7(2), 1013.
Witasari, A. (2011). Konsekuensi hukum bagi seorang arbiter dalam memutus suatu perkara berdasarkan Undang-Undang No. 30 Tahun 1999. Jurnal Hukum, 25(1), 474-489. 


\section{Lampiran}
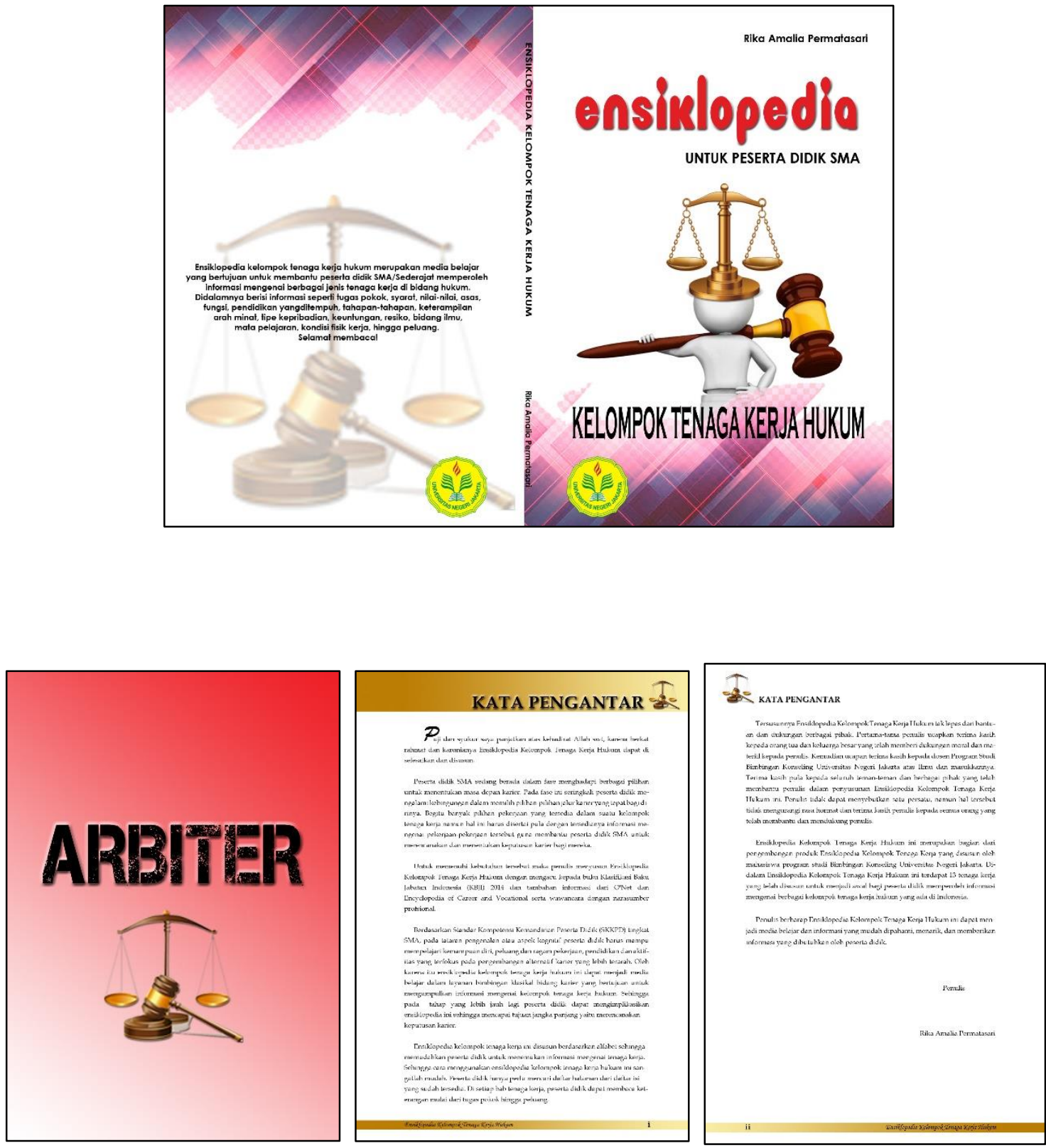

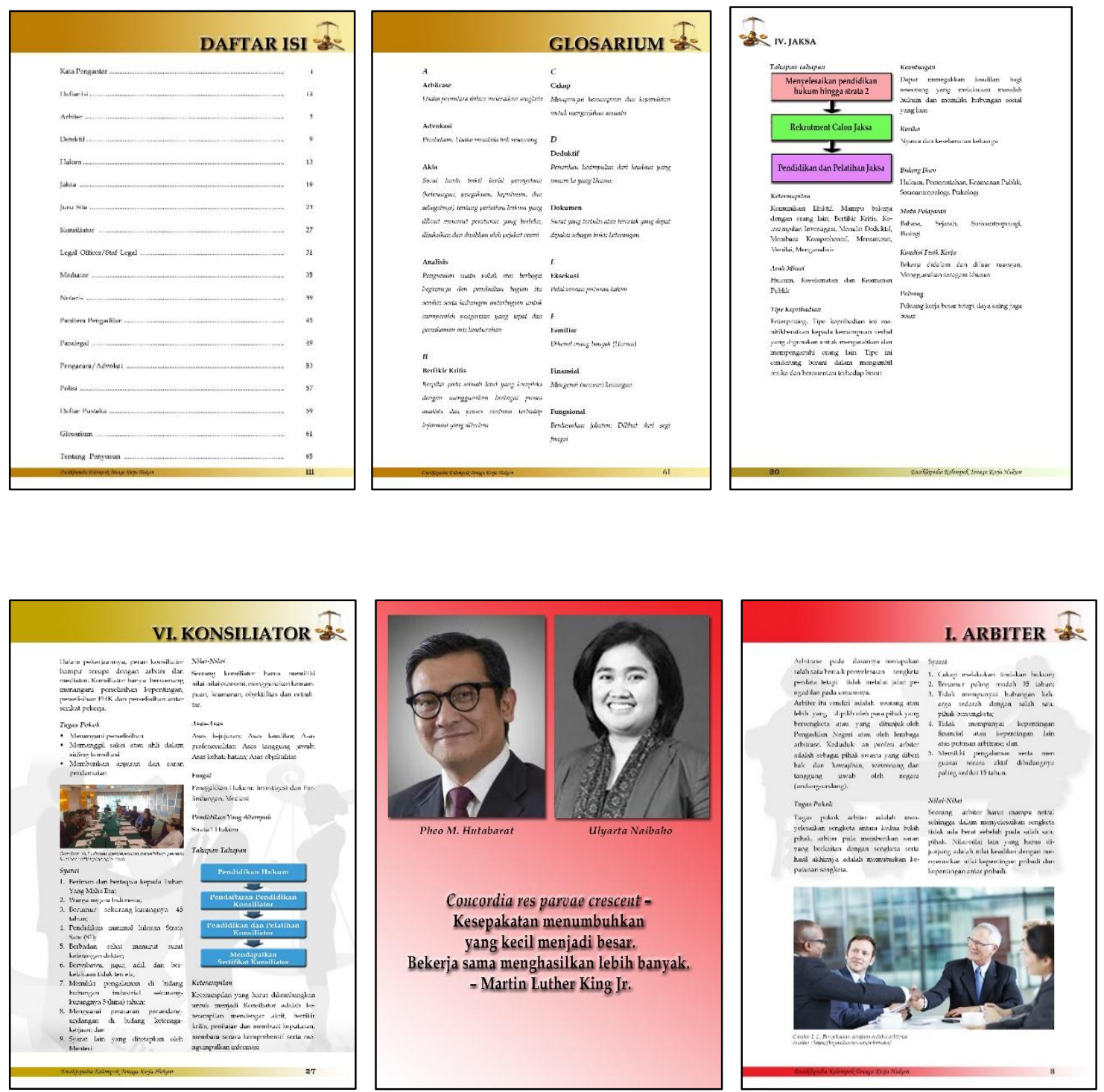